УДК 351.88: 327.39

DOI: https://doi.org/10.32689/2618-0065-2020-1(3)-153-162

Рєзніков Валерій Володимирович, кандидат економічних наук, доцент, докторант навчально-науково-виробничого центру, Національний університет цивільного захисту України, 61024, м. Харків, вул. Лермонтовська, 28, тел. (050) 632-16-93, e-mail: osvita00@gmail.com

ORCID: 0000-0002-3579-3114

\title{
ОСОБЛИВОСТІ ФОРМУВАННЯ ТА РЕАЛІЗАЦІЇ ДЕРЖАВНОЇ ПОЛІТИКИ У СФЕРІ ЄВРОПЕЙСЬКОЇ ІНТЕГРАЦІЇ В РІЗНИХ КРАЇ̈АX
}

Анотація. Україна проголосила вступ до ЄС одним зі стратегічних питань зовнішньої політики, однак відносини з Європейським Союзом в цьому питанні поки знаходяться на початковому етапі. Така ситуація склалася, як через повільність реформ в Україні так і через небажання СС починати нову хвилю розширення.

Хоча в світі за останні десятиліття багато країн Свропи пройшли євроінтеграційний шлях, однак недостатньо фундаментальних, а не фрагментарних досліджень щодо оцінки переваг та ризиків інтеграції, а також аналізу існуючого досвіду. Також недостатньо експертних оцінок щодо впливу різних факторів на конкретні напрями необхідних трансформацій, які мають відбутися в процесі інтеграції України.

Основними завдання, які стоять перед державами та реалізуються в рамках європейської інтеграції є: соціально-економічне посилення країни, як внутрішнє так і по відношенню до третіх країн; зміцнення позицій країни на міжнародно-політичному рівні; внутрішня політична стабільність країни. А головною запорукою успішності реалізації Стратегії інтеграції різних країн до $Є \mathrm{C} \epsilon$ перехід від декларування намірів стати повноправним членом $Є \mathrm{C}$ до конкретних дій, які мають бути спрямовані в першу чергу на побудову вільного демократичного суспільства, зменшення ролі держави в управлінні економікою, боротьбу з корупцією та тіньовою економікою.

Узагальнення світового досвіду реалізації державної політики у сфері європейської інтеграції дозволило виявити методологічні підходи, механізми, інструменти та принципи для використання в українській державноуправлінській практиці. Досвід більшості країн вказує на те, що швидкого та легкого способу вступу до ЄС не існує: це довгий та складний євроінтеграційний шлях. Тому державна політика у сфері європейської інтеграції України має сприяти перетворенням у політичній, правовій, економічній, фінансовій, соціальній, екологічній сферах, що дозволить подолати більшість труднощів на шляху європейської інтеграції і дозволить нашій країні стати невід'ємною частиною оновленої Свропи. 
Ключові слова: європейська інтеграція, державна політика у сфері європейської інтеграції, механізми формування та реалізації державної політики у сфері європейської інтеграції.

Ryeznikov Valeriy Volodymyrovych, $\mathrm{PhD}$ in Economic Sciences, associate professor, doctoral student of educational-scientific-production center, National University of Civil Protection of Ukraine, 61024, Kharkiv, Str. Lermontovs'ka, 28, tel.: (050) 632-16-93, e-mail: osvita00@gmail.com

ORCID: 0000-0002-3579-3114

\title{
PECULIARITIES OF FORMATION AND IMPLEMENTATION OF STATE POLICY IN EUROPEAN INTEGRATION IN DIFFERENT COUNTRIES
}

\begin{abstract}
Ukraine has declared accession to the EU one of the strategic foreign policy issues, but relations with the European Union are still in the initial stage. This is the situation, both because of the slow pace of reforms in Ukraine and because of the reluctance of the EU to start a new wave of expansion.

Although many countries in Europe have gone through the European integration path in the last decades, there is insufficient fundamental rather than fragmented research on the benefits and risks of integration, as well as the analysis of existing experience. There is also insufficient expert judgment on the impact of various factors on the specific directions of the necessary transformations that are to take place in the process of Ukraine's integration.

The main tasks facing states and pursued within the framework of European integration are: socio-economic strengthening of the country, both internally and vis-à-vis third countries; strengthening the country's position at the international political level; internal political stability of the country and so on. The main key to the success of the implementation of the EU Integration Strategy is the transition from declaring intentions to become a full member of the EU to concrete actions, which should be aimed primarily at building a free democratic society, reducing the role of the state in governing the economy, combating corruption and the shadow economy.

Generalization of the world experience in the implementation of state policy in the sphere of European integration made it possible to identify methodological approaches, mechanisms, tools and principles for use in Ukrainian public administration practice. The experience of most countries indicates that there is no quick and easy way to join the EU: it is a long and difficult European integration path. Therefore, the state policy in the sphere of European integration of Ukraine should promote transformation in the political, legal, economic, financial, social, environmental spheres, which will overcome most of the difficulties in the path of European integration and will allow our country to become an integral part of a renewed Europe.
\end{abstract}


Keywords: European integration, state policy in the sphere of European integration, mechanisms of formation and implementation of state policy in the sphere of European integration.

Постановка проблеми. Україна стала на шлях європейської інтеграції після розпаду Радянського Союзу, зробивши вибір на користь європейських демократичних цінностей та свобод. Свропейський вибір України $\epsilon$ виваженим та послідовним рішенням, що потребує відповідних зусиль щодо проходження відповідного євроінтеграційного шляху на основі комплексного узагальнення досвіду країн, що вже пройшли або проходять шлях інтеграції в ЄC. Одним із дієвих способів успішної інтеграції нашої держави до Євросоюзу є глибокий аналіз відповідних процесів у тих державах, які вже вступили в цю співдружність або мають статус кандидата на вступ.

Аналіз останніх досліджень і публікацій. Розгляду особливостей формування та реалізації державної політики у сфері європейської інтеграції в різних країнах світу присвятили свої публікації такі вчені, як Артьомов I., Ващук О., Діус Н., Молдован А., Руденко О., Янчук Л. та інші. Однак чимало питань стосовно напрямів та можливостей адаптації світового досвіду реалізації державної політики у сфері європейської інтеграції в Україні залишаються недостатньо дослідженими.

Метою статті $є$ визначення особливостей формування та реалізації державної політики у сфері європейської інтеграції в різних країнах світу, а також можливостей їх імплементації в Україні.

Виклад основного матеріалу. Україна проголосила вступ до $\mathrm{CC}$ одним зі стратегічних питань зовнішньої політики, однак відносини 3 Свропейським Союзом в цьому питанні поки знаходяться на початковому етапі. Така ситуація склалася, як через повільність реформ в Україні так i через небажання ЄС починати нову хвилю розширення.

Хоча в світі за останні десятиліття багато країн Свропи пройшли євроінтеграційний шлях, однак недостатньо фундаментальних, а не фрагментарних досліджень щодо оцінки переваг та ризиків інтеграції, а також аналізу існуючого досвіду. Також недостатньо експертних оцінок щодо впливу різних факторів на конкретні напрями необхідних трансформацій, які мають відбутися в процесі інтеграції України.

Дуже корисним для України на їі шляху до Свропейського Союзу є досвід держав Балтії, набутий ними в процесі європейської інтеграції, адже Україна та країни Балтії мають багато спільних рис, по-перше, їх об’єднує спільне минуле, по-друге, це країни, що на початку 1990-х почали будівництво самостійної та демократичної держави, проголосивши курс на співпрацю з Свропейським Союзом.

Отже, пострадянські республіки: Латвія, Литва та Естонія змогли за дуже короткий термін подолати складнощі перехідного періоду, провести реформування економіки, системи управління державою, соціальної сфери 
життя та вступити до СС. Тому дослідження пройденого реформаційного шляху цих трьох держав має значний практичний інтерес для України.

Країнам Балтії довелося подолати важкий шлях 3 виконання основних критеріїв членства в Свропейському Союзі, хоча вони були досить високими для цих країн того часу. Молодим незалежним країнам довелося адаптувати власне законодавство під норми $\mathrm{CC}$, а це 31 розділ, що містять сотні законодавчих актів, які грунтуються на «Договорі про заснування Європейської співдружності» та доповненнях до нього, саме цей Договір визначає конкретні напрямки за якими було створено загальноєвропейське законодавство. Країнам Балтії довелося адаптуватися під велику частину усього комплексу європейського законодавства. За цей час докорінні зміни торкнулися економічної, соціальної та політичної сфери життя країн. Зокрема, довелося адаптувати законодавство у сфері вільного руху мешканців країн-членів, товарів, капіталу, а також у сфері конкурентної політики. Єдина сфера де не потребувалася адаптація національного законодавства до норм СС - це культура: Євросоюз лише всіляко підтримує та сприяє розвитку культури кожної держави, не потребуючи при цьому створення спільної законодавчої бази [1].

Щоб краще усвідомлювати користь досвіду інтеграції держав Балтії, Ковтун Є. пропонує розглянути процес вступу країн Балтії до СС поетапно.

На його думку, першим етапом можна вважати базисний період 19911994 рр., коли Латвія, Литва та Естонія проходять шлях від визнання своєї незалежності Свросоюзом до підписання між цими сторонами угод про вільну торгівлю, які стали базисом економічної співпраці між ЄС та державами Балтії, а також запорукою подальшого розвитку відносин між ними. Протягом цього часу розвивається поглиблений економічний діалог між ЄС та Балтійськими державами. В економічному плані країнам довелося пристосовуватися до нових умов, що створювалися через упровадження загальноєвропейського торгового, фінансового та митного законодавства. За таких обставин, ринок країн відкривався для безперешкодного доступу більш конкурентоспроможних товарів з СС, але й Латвія, Литва та Естонія також мали змогу просувати свою продукцію на європейські ринки.

Другий етап (1995-1998рр.) розпочався 3 підписання договорів про асоційоване членство Латвії, Литви та Естонії. В цей період відносини між Балтійськими республіками і СС виходять на якісно новий рівень визначення чітких завдань до подальшої співпраці в руслі інтеграції до Свросоюзу і саме в цей період держави Балтії подають заявки на вступ до ЄС.

Третій етап (1998-2003 рр.) розпочався представленням Рішень ради Європейського Союзу з чіткими вимогами до країн-кандидатів на вступ до ЄС. Протягом цього етапу поглиблюються не тільки економічні зв'язки між ЄC і країнами Балтії, а й співпраця в політичній і соціальній сферах. Також Латвія, Литва та Естонія, отримавши чіткі вимоги від Свросоюзу, починають їх виконувати. Піковою подією етапу можна назвати саміт ЄC в Афінах, під 
час якого, 16 квітня 2003 р. були підписані угоди про вступ з десятьма країнами: Болгарією, Чехією, Естонією, Угорщиною, Латвією, Литвою, Польщею, Румунією, Словаччиною та Словенією. Остаточною датою вступу країн Балтії до СС є 1 травня 2004 р., коли вони разом з сімома іншими державами офіційно набули повноправного членства.

Розширення $\mathrm{CC}$, яке відбулося у 2004 р. вплинуло безпосередньо і на Україну, адже в стратегічному плані, розширення СС стало важливим чинником подальшої європейської інтеграції нашої країни, за рахунок якої виникли більш широкі можливості розвитку всебічного співробітництва та поглиблення взаємодії між сторонами.

Свропейська інтеграція для країн Балтії стала головним фактором, який в значній мірі вплинув на розвиток цих країн, адже шлях до Свросоюзу виступив головним каталізатором проведення реформ та економічного зростання. Хоча на момент вступу до $\mathrm{EC}$, економічні показники Латвії, Литви та Естонії були одними 3 найнижчих серед країн-членів, економіка прибалтійських республік характеризувалася високими темпами зростання, що дозволило їм значно випередити усі колишні радянські республіки. 3 набуттям повноправного членства в СС збільшилася також політична вага цих держав, зріс їхній міжнародний імідж [2].

Цінним джерелом корисного досвіду євроінтеграції для України $\epsilon$ відносини $з$ країнами Вишеградської четвірки (В-4), які для нашої країни завжди мали важливе значення, адже три з чотирьох країн цього об'єднання $\epsilon$ сусідніми для України державами, а також всі чотири країни стали прикладом успішного набуття членства в Європейському Союзі і можуть надати відповідну авторитетну підтримку для просування євроінтеграційних прагнень України.

Країни Вишеградської угоди - це група 3 чотирьох країн, до якої увійшли Польща, Словаччина, Чехія й Угорщина, створена в угорському місті Вишеграді у лютому 1991 р. для координації зусиль на шляху вступу до HATO і ЄС. Країни поставили за мету повну господарську, політичну й юридичну інтеграцію до СС і вступ до НАТО. У 1999 р. до НАТО вступили Польща, Угорщина і Чехія; у 2003 р. - Словаччина. 1 травня 2004 р. всі чотири «Вишеградські країни» увійшли до Європейського Союзу [3].

Польща, як і Україна - постсоціалістична держава, що мала приблизно однакові стартові позиції на початку трансформаційних перетворень, досить схожу структуру економіки, подібне складне геополітичне становище i поляризовану політичну систему. Однак Польща, яка ще в 90-х роках минулого століття чітко дотримувалася курсу на євроінтеграцію, досягла значних економічних успіхів у порівнянні 3 Україною, яка намагалася отримати дивіденди, декларуючи інтеграційні прагнення одночасно в східному і західному напрямках. Незважаючи на наявні проблеми, інтеграція Польщі в СС корелює зі значним поліпшенням абсолютної більшості показників соціально-економічного розвитку держави. 
Досягти цього прогресу їй вдалося завдяки можливостям і вигодам, наданим Польщі членством в ЄС. Це такі вигоди, як поліпшення бізнесклімату, зміцнення ринкової економіки, створення ефективної системи захисту прав власності, прямий доступ до фінансових ринків європейських країн, відсутність митних бар'єрів в рамках Європейського Союзу.

До речі, комплекс проблем, з якими зараз стикається Україна, подібний до проблем, які були притаманні Польщі (як, зрештою, й іншим постсоціалістичним державам регіону) перед початком руху в європейському напрямку. До слова, навіть сьогодні в Польщі спалахують скандали щодо різних фінансових афер, зловживань чиновників, нецільового використання бюджетних коштів, ухилення підприємств від сплати податків. Але саме тут членство країни в СС відіграє значну конструктивну роль.

Так, Європейський суд активно блокує будь-які спроби органів державної влади спотворити ринковий простір та створити неринкові переваги для окремих суб'єктів. Свропейська комісія стежить за ефективністю та обгрунтованістю витрачання значної частини публічних коштів (насамперед, одержуваних Польщею зі структурних фондів ЄС), що автоматично формує антикорупційну культуру у чиновників. Свропейські компанії сформували цивілізований діловий клімат, де домінують принципи прозорості, чесної конкуренції та партнерського діалогу 3 органами державної влади [4].

Вступ іншої країни Вишеградської групи - Словаччини до Свросоюзу стало одним із пріоритетів зовнішньої політики 3 моменту створення незалежної держави в 1993 р. Головна ідея і сенс інтеграції полягав в тому, що республіка, вступивши в ЄС, стане частиною потужного проекту, який підтримає функціонування демократичних інститутів, верховенство права, сприятиме економічному та соціальному розвитку, дасть імпульс розвитку регіонів, позитивно вплине на підприємницьку сферу i сприятиме поліпшенню стану навколишнього середовища. Для досягнення цієї мети Словаччина реалізувала масштабні економічні та соціальні реформи, взяла на себе зобов'язання, пов'язані 3 членством в $\mathrm{CC}$, а також виконала Копенгагенські критерії [5].

Для створення скоординованої системи роботи словацьких державних органів в умовах інтеграції i подальшого функціонування в рамках об'єднання, державні відомства посилювалися кадровими ресурсами. Потреба в професійних кадрах, які розбиралися в імплементації законодавства, реформування державних і самоврядних органів і могли б здійснити структурні зміни відповідно до вимог СС, виникла в Словаччині на початку інтеграції та існує дотепер.

Така підготовка реалізується в таких напрямках:

- $\quad$ створення спеціальних навчальних програм у вищих навчальних закладах з одночасним поглибленим вивченням іноземних мов; 
- запозичення досвіду інших держав-членів Євросоюзу через програми стажування та створення спільних робочих груп;

- допомога громадських організацій в розробці та вдосконаленні законодавства;

- $\quad$ стажування словацьких чиновників в структурах ЄС [6].

Вищевказані фактори стали визначальними у питаннях ефективного реформування різних секторів, галузей та сфер суспільного життя в процесі трансформації та європейської інтеграції Словаччини.

Для всебічного аналізу процесу європейської інтеграції Словаччини необхідно також звернути увагу на політичну культуру i підтримку населенням процесу інтеграції.

Загальновідомо, що в демократичному суспільстві неможливо ігнорувати громадську думку. Після закінчення переговорів про вступ Словаччина оголосила про проведення референдуму, під час якого громадяни країни відповідали на питання «Чи згодні ви, щоб Словацька Республіка стала державою-членом Свропейського Союзу?». У референдумі взяли участь 52,15\% виборців, а за вступ країни в СС висловилися 92,46\% тих, хто голосував, що підтвердило підтримку словаками європейського вибору [7].

До речі, в Україні, згідно з дослідженням проведеним соціологічною службою Центру Разумкова з 17 по 21 січня 2020 р., якби найближчим часом відбувся референдум 3 приводу вступу України до ЄС, то майже дві третини $(63,3 \%)$ усіх опитаних проголосували б за вступ. Проти проголосували б $21,6 \%$ респондентів, решта не брали б участь у референдумі або не визначилися 3 відповіддю. За вступ до ЄС проголосували б абсолютна більшість респондентів у Західному (78,4\%), Центральному (68,7\%) та Південному $(51,5 \%)$ регіонах, а також відносна більшість опитаних у Східному регіоні $(46,8 \%)$ [8].

Отже, на прикладі Польщі та Словаччини можна наочно побачити, які вигоди чекають Україну в разі повноцінної інтеграції в ЄС. В цілому загроз для вітчизняної економіки в європейський вектор інтеграції чимало, але i потенційні вигоди дуже привабливі. Домогтися успіхів у цьому напрямку можна при наявності політичної волі керівництва країни довести це рух до повноцінної інтеграції в СС.

Слід зазначити, що держави В-4 надають відчутну політичну підтримку євроінтеграційному курсу нашої держави в рамках так званої «групи друзів» України в СС, під час головування в Свросоюзі, офіційно підтримуючи План дій Україна - СС. Одночасно співпраця ведеться у різних формах: зміцнення міжурядових контактів, урізноманітнення заходів у форматі «В-4 + Україна» у політико-безпековій, військовій, енергетичній, соціокультурній сферах, а також на регіональному рівні [9].

В цілому, експерти, опитані в Польщі, Чехії і Словаччини, вважають, що курс на євроінтеграцію мав важливе значення в здійсненні внутрішніх реформ у цих країнах. Більшість словацьких експертів переконана, що роль 
європейської інтеграції була вирішальною для внутрішніх трансформацій. Експерти в Польщі і Чехії розділилися на дві групи - одна вважає, що євроінтеграційний курс зіграв ключову роль для внутрішніх реформ, інша окреслює цю роль як важливу, однак не визначальну [10].

Таким чином, співпраця між Україною та Вишеградською четвіркою $\epsilon$ ефективною та перспективною, здебільшого в плані отримання стимулів та відповідної допомоги Україні на шляху інтеграції до Європейського Союзу.

Отже, світовий досвід свідчить, що основними завдання, які стоять перед державами та реалізуються в рамках європейської інтеграції є: соціально-економічне посилення країни, як внутрішнє так і по відношенню до третіх країн; зміцнення позицій країни на міжнародно-політичному рівні; внутрішня політична стабільність країни тощо. А головною запорукою успішності реалізації Стратегії інтеграції різних країн до ЄС $є$ перехід від декларування намірів стати повноправним членом СС до конкретних дій, які мають бути спрямовані в першу чергу на побудову вільного демократичного суспільства, зменшення ролі держави в управлінні економікою, боротьбу 3 корупцією та тіньовою економікою.

Тому Україні доцільно розвивати двостороннє співробітництво 3 країнами, які успішно пройшли чи проходять шлях європейської інтеграції. $€$ потреба в активізації діалогу та визначення перспективних сфер співробітництва, зокрема 3 вивчення євроінтеграційного досвіду, в тому числі щодо адаптації національного законодавства до стандартів ЄС.

На наш погляд, ефективним діалогом може стати підписання з цими країнами Меморандумів про співпрацю в галузі європейської інтеграції. Меморандум допоможе визначити сфери, які потребують підтримки в період проведення Україною важливих для європейської інтеграції судових, адміністративних, інституційних та інших реформ. Крім того, добросусідські відносини, закріплені Меморандумом, є гарантом довгострокової безпеки і стабільності в регіоні, важливим елементом європейської інтеграції. Серед держав-членів СС Україні потрібно поглиблювати співпрацю 3 державами, які мали схожі проблеми на шляху до євроінтеграції, особливо з країнами колишнього соціалістичного табору, які з Україною знаходились майже в тотожних соціально-економічних умовах розвитку на початку євроінтеграції.

Висновки. Отже, узагальнення світового досвіду реалізації державної політики у сфері європейської інтеграції дозволило виявити методичні підходи, механізми, інструменти та принципи для використання в українській державноуправлінській практиці. Досвід більшості країн, особливо східноєвропейських держав вказує на те, що швидкого та легкого способу вступу до СС не існує: це довгий та складний євроінтеграційний шлях. Тому державна політика у сфері європейської інтеграції України має сприяти перетворенням у політичній, правовій, економічній, фінансовій, соціальній, екологічній сферах, що дозволить подолати більшість труднощів на шляху європейської інтеграції і дозволить нашій країні стати невід'ємною 
частиною оновленої Свропи, що й буде предметом подальших наукових досліджень.

\section{Лimepamypa:}

1. Договір про заснування Європейської Спільноти // Конституційні акти Європейського Союзу. [Під. ред. Т. Качки]. - К.: Юстиніан, 2005. - С. 46-183.

2. Ковтун Є. Досвід інтеграції Латвії, Литви та Естонії до Європейського Союзу, як приклад для України / С. Ковтун. [Електронний ресурс]. - Режим доступу : http://dspace.nbuv.gov.ua/handle/123456789/110824.

3. Артьомов I.В. Єврорегіональне співробітництво України: проблеми i перспективи: навч.-метод. посібник / І.В. Артьомов, Н.О. Діус. - Ужгород: ПП «Шарк», 2014. -368 c.

4. Молдован А. Интеграция в ЕС: опыт Польши и вызовы для Украины / A. Молдован. [Електронний ресурс]. - Режим доступу : https://zn.ua/macrolevel/integraciya-ves-opyt-polshi-i-vyzovy-dlya-ukrainy-.html.

5. Зубро Т. Политико-экономические аспекты европейской интеграции: опыт Словацкой Республики // Т. Зубро, Д. Адашкова / Науковий вісник Ужгородського національного університету. Світове господарство і міжнародні економічні відносини: зб. наук. пр. - Ужгород. Видавничий дім «Гельветика». - 2015. - №10 (172). - С. 19-27.

6. Янчук Л. Європейська інтеграція Словацької Республіки (1993-2004) // Український історичний збірник. - Вип. 11. - К., 2008. - С. 317-324.

7. Зубро Т. Политико-экономические аспекты европейской интеграции: опыт Словацкой Республики // Т. Зубро, Д. Адашкова / Науковий вісник Ужгородського національного університету. Світове господарство і міжнародні економічні відносини: зб. наук. пр. - Ужгород. Видавничий дім «Гельветика». - 2015. - №10 (172). - С. 19-27.

8. Рівень підтримки громадянами вступу Украйни до СС та НАТО (січень 2020 р.). [Електронний ресурс]. - Режим доступу : http://razumkov.org.ua/napriamky/sotsiologichnidoslidzhennia/riven-pidtrymky-gromadianamy-vstupu-ukrainy-do-yes-ta-nato-sichen-2020r.

9. Артьомов І.В. Регіональна політика країн Вишеградської четвірки: досвід для України // І.В. Артьомов, Н.О. Діус / Моделі і механізми регулювання єврорегіонального співробітництва України / За заг. ред. І.В.Артьомова, О.М.Ващук, О.М.Руденко. Ужгород: МПП «Гражда», 2013. - С. 49-66.

10. В Запорожье провели круглый стол «Европейская интеграция Вышеградских стран: опыт реформ и уроки для Украины». [Електронний ресурс]. - Режим доступу : http://www.potencial.org.ua/ru/view/news/u-zaporiggi-proveli-krugliy-stil-ievropeyskaintegratsiya-vishegradskih-krain-dosvid-reform-ta-uroki-dlya-ukraini.html.

\section{References:}

1. Kachka, T. (Eds.) (2005). Dohovir pro zasnuvannya Yevropeys'koyi Spil’noty [Treaty establishing the European Community]. Konstytutsiyni akty Yevropeys'koho Soyuzu. Constitutional acts of the European Union. - K.: Yustynian [in Ukrainian].

2. Kovtun, Ye. Dosvid intehratsiyi Latviyi, Lytvy ta Estoniyi do Yevropeys'koho Soyuzu, yak pryklad dlya Ukrayiny [Experience of integration of Latvia, Lithuania and Estonia into the European Union as an example for Ukraine]. (n.d.). dspace.nbuv.gov.ua. Retrieved from : http://dspace.nbuv.gov.ua/handle/123456789/110824. [in Ukrainian].

3. Art'omov, I.V., \& Dius, N.O. (2014). Yevrorehional'ne spivrobitnytstvo Ukrayiny: problemy i perspektyvy [Euroregional cooperation of Ukraine: problems and prospects]. Uzhhorod: PP «Shark» [in Ukrainian].

4. Moldovan, A. Integratsiya $v$ YES: opyt Pol'shi i vyzovy dlya Ukrainy [EU Integration: Polish Experience and Challenges for Ukraine]. (n.d.). zn.ua. Retrieved from : 
https://zn.ua/macrolevel/integraciya-v-es-opyt-polshi-i-vyzovy-dlya-ukrainy-.html. [in Russian].

5. Zubro, T., \& Adashkova, D. (2015). Polytyko-ékonomycheskye aspekty evropeyskoy yntehratsyy: opyt Slovatskoy Respublyky [Political and economic aspects of European integration: the experience of the Slovak Republic]. Naukovyy visnyk Uzhhorods'koho natsional'noho universytetu. Svitove hospodarstvo i mizhnarodni ekonomichni vidnosyny, 10 (172), 19-27 [in Russian].

6. Yanchuk, L. (2008). Yevropeys’ka intehratsiya Slovats’koyi Respubliky (1993-2004) [European Integration of the Slovak Republic (1993-2004)]. Ukrayins'kyy istorychnyy zbirnyk, 11, 317-324 [in Ukrainian].

7. Zubro, T., \& Adashkova, D. (2015). Polytyko-ékonomycheskye aspekty evropeyskoy yntehratsyy: opyt Slovatskoy Respublyky [Political and economic aspects of European integration: the experience of the Slovak Republic]. Naukovyy visnyk Uzhhorods'koho natsional'noho universytetu. Svitove hospodarstvo i mizhnarodni ekonomichni vidnosyny, 10 (172), 19-27 [in Russian].

8. Riven’ pidtrymky hromadyanamy vstupu Ukrayiny do YES ta NATO (sichen’2020r.). [Level of citizens' support for Ukraine's accession to the EU and NATO (January 2020)]. (n.d.). razumkov.org.ua. Retrieved from http://razumkov.org.ua/napriamky/sotsiologichnidoslidzhennia/riven-pidtrymky-gromadianamy-vstupu-ukrainy-do-yes-ta-nato-sichen-2020r. [in Ukrainian].

9. Art'omov, I.V., \& Dius, N.O. (2013). Rehional'na polityka krayin Vyshehrads'koyi chetvirky: dosvid dlya Ukrayiny [Regional policy of the Visegrad countries: experience for Ukraine]. Modeli i mekhanizmy rehulyuvannya yevrorehional'noho spivrobitnytstva Ukrayiny. I.V. Art'omova (Ed.)., O.M. Vashchuk (Ed.)., O.M. Rudenko (Ed.). Uzhhorod: MPP «Hrazhda» [in Ukrainian].

10. V Zaporozh'ye proveli kruglyy stol «Yevropeyskaya integratsiya Vyshegradskikh stran: opyt reform i uroki dlya Ukrainy». [In Zaporozhye, a round table was held on "European Integration of Visegrad Countries: Reform Experience and Lessons for Ukraine”]. (n.d.). potencial.org.ua Retrieved from http://www.potencial.org.ua/ru/view/news/u-zaporiggi-provelikrugliy-stil-ievropeyska-integratsiya-vishegradskih-krain-dosvid-reform-ta-uroki-dlyaukraini.html. [in Russian]. 